\title{
Molybdenum Cofactor Deficiency
}

National Cancer Institute

\section{Source}

National Cancer Institute. Molybdenum Cofactor Deficiency. NCI Thesaurus. Code C129076.

An autosomal recessive condition that is caused by mutation(s) in the MOCS1 gene, encoding molybdenum cofactor biosynthesis protein 1. it is characterized by poor feeding, encephalopathy, seizures and dysmorphic facial features. 